\title{
Pentagamavunone-0 (PGV-0), a Curcumin Analog, Enhances Cytotoxicity of 5-Fluorouracil and Modulates Cell Cycle in WiDr Colon Cancer Cells
}

\author{
Muthi Ikawati ${ }^{1,2, *}$ and Endah Puji Septisetyani, ${ }^{1, \#}$ \\ ${ }^{1}$ Cancer Chemoprevention Research Center, Faculty of Pharmacy, Universitas Gadjah Mada, Indonesia \\ ${ }^{2}$ Department of Pharmaceutical Chemistry, Faculty of Pharmacy, Universitas Gadjah MadaIndonesia \\ ${ }^{\#}$ Current address: Research Center for Biotechnology, Indonesian Institute of Sciences, Cibinong, Indonesia
}

\begin{abstract}
The use of 5-fluorouracil (5-FU) in colon cancer as the primary chemotherapy has not been meet satisfactory effectiveness. Therefore, the development of new chemicals as a chemopreventive agent and a combination agent (co-chemotherapeutic agent) for colon cancer is important. Pentagamavunone-0 (2,5-bis-(4'-hydroxy-3'-methoxybenzylidine) cyclopentanone) (PGV-0), one of curcumin analogs, exhibits cytotoxic effect and apoptosis induction in various cancer cell lines, including colon cancer cell, better than curcumin. This study aimed to investigate the cytotoxic potency of PGV-0 in combination with 5-FU and their effects, in single or in combination, on cell cycle toward WiDr colon cancer cell line. The cells were treated with combination concentrations of PGV-0 and 5-FU, and examined by MTT cell viability assay. The value of combination index $(\mathrm{Cl})$ as a parameter of cytotoxic combination assay was measured by a combination index method. Cells were stained with propidium iodide and the cell cycle distribution was determined by flowcytometry. $\mathrm{Cl}$ calculation showed additive effects between PGV-0 and 5-FU. Combination of PGV-0 and 5-FU gave synergism on cell cycle. Single treatment of PGV-0 increased apoptosis, illustrated as subGIphase accumulation, stronger than single treatment of 5-FU. Meanwhile, combination of PGV-0 and 5-FU demonstrated S-phase arrest. Based on these results, it can be concluded that PGV-O has the potential to be developed as a co-chemotherapeutic agent for colon cancer but still requires further tracking of its molecular mechanisms.
\end{abstract}

Keywords: Pentagamavunone-0 (PGV-0), 5-fluorouracil (5-FU), colon cancer, combination, cell cycle

\section{INTRODUCTION}

Colon cancer, one of the leading causes of cancer death (Jemal, et al., 2006) is one of the diseases suffered by many modern humans because of the shift in dietary that tends to be less fiber and high fat. Colon cancer chemotherapy uses 5fluorouracil (5-FU), a cytotoxic agent, as the main choice of conventional agents (Arkenau, et al., 2005). Nevertheless, the effectiveness of therapy with 5-FU only reached $20 \%$. In fact, some types of cancer cells show resistance to 5-FU (De Angelis, et al., 2006). Development of colon cancer therapy should be directed to find a potential chemopreventive agent as well as a combination agent (cochemotherapy) that can increase the effectiveness and decrease the side effects of 5-FU.Curcumin is a natural compound isolated from the rhizome of turmeric (Curcuma longa). Curcumin is known to have anti-inflammatory activity and is able to inhibit the growth of several types of cancer cells (reviewed by Aggarwal, et al., 2005). However, curcumin has low bioavailability so it does not show a significant effect in vivo. In spite of its bioavailability issue, curcumin still provides hope for colon cancer treatment because curcumin may last longer in the gastric and interact with intestinal tissue (Sharma, et al., 2004). Therefore, development of curcumin analogs to find more potent compounds, especially to overcome colon cancer, needs to be executed.

For the above purposes, National Molecule Team from Faculty of Pharmacy Universitas Gadjah Mada (UGM) has synthesized curcumin analogs namely Pentagamavunone-0 (PGV-0) (2,5-bis- (4'hydroxy- 3' -methoxybenzylidine) - cyclopentanone)

Submitted: Feb 15, 2018

Revised: Feb 20, 2018

Accepted: Feb 20, 2018

*Corresponding author e-mail: muthi_ikawati@ugm.ac.id 
(Reksohadiprodjo, et al., 2004). PGV-0 possesses potent cytotoxicity against several types of cancer cell lines, i.e., HeLa cervical cancer cells (Meiyanto, et al., 2003), Raji lymphoma cells, myeloma cells (Da'i, 2003), T47D breast cancer cells (Da'I, et al., 2007), WiDr colon cancer cell (Septisetyani, et al., 2008), and MCF-7 breast cancer cells (Hermawan, et al., 2011). Moreover, PGV-0 shows stronger cytotoxicity than curcumin in breast cancer cell lines (Meiyanto, et al., 2006; Nurulita and Meiyanto, 2006; Meiyanto, et al., 2014) and colon cancer cell line (Septisetyani, et al., 2008). PGV-0 also has low bioavailability (Suwaldi and Oetari, 2004), so it is appropriate for colon cancer treatment. Compared to curcumin, PGV-0 has greater potency because it performs better pharmacological effects, more stable, and does not show toxic effect based on acute and subchronic toxicity test in rats (National Molecule Team, 2001할 National Molecule Team, $2001^{\mathrm{b}}$ ).

Previously, it has been reported that PGV-0 exhibits stronger cytotoxic effect and apoptotic induction in WiDr colon cancer cells compared to curcumin (Septisetyani, et al., 2008). This present study aimed to further investigate the potency of PGV-0 as co-chemotherapy agent by cytotoxicity assay of PGV-0 in combination with 5-FU. This work also investigated the effects of PGV-0, in single or in combination, on cell cycle toward WiDr cells, as a model of colon cancer cell that resistant to chemotherapy agents. Combination cytotoxicity assay and cell cycle analysis were performed as a preliminary step for PGV-0 development as a chemopreventive agent and a co-chemotherapy agent for colon cancer. The results of this study are expected to be a strong foundation for the development of PGV-0 for colon cancer therapy.

\section{MATERIALS AND METHODS}

\section{Materials}

PGV-0 (HPLC purity grade) was obtained from Curcumin Research Center (CRC) Faculty of Pharmacy UGM. The stock solution of PGV-0 was made by dissolving it in DMSO (DMSO 99.5\% pro GC, Sigma Aldrich, Germany). 5-Fluorouracil $(250 \mathrm{mg} / \mathrm{ml})$ preparation was from Ferron Par Pharmaceutical (Cikarang, Indonesia).

\section{Cell culture}

WiDr colon cancer cells were a collection of Cancer Chemoprevention Research Center (CCRC) Faculty of Pharmacy UGM. Cells were grown in RPMI 1640 medium (Gibco, USA) supplemented by $10 \%$ foetal bovine serum (FBS) (Gibco, USA) and $1 \%(\mathrm{v} / \mathrm{v})$ penicillin-streptomycin (Gibco, USA) and cultured in the $\mathrm{CO}_{2}$ incubator at $37^{\circ} \mathrm{C}$. Cells were harvested from culture dish or flask with trypsinEDTA $0.025 \%$ (Gibco, Canada) at $80 \%$ confluence.

\section{Cytotoxic combination assay}

Cytotoxic combination assay was performed as previously described (Hermawan, et al., 2011) by MTT cell viability assay (Mossman, 1983). Briefly, the cells were plated in 96-well microplate at a density of $5 \times 10^{3}$ cells/well. Forty eight hours after plating, the medium was replaced with a medium containing single or combination of PGV-0 and 5FU. The following concentrations based on inhibitory concentration of $50 \% \quad\left(\mathrm{IC}_{50}\right)$ were introduced : 1/8, 1/4, 3/8, 1/2 of $\mathrm{IC}_{50}$ for PGV-0 or $1 / 6,1 / 3,1 / 2,7 / 10$ of $\mathrm{IC}_{50}$ for $5-\mathrm{FU}$, respectively. After 24 hour (h) incubation with respective concentration of chemicals the solution was replaced by $50 \mu \mathrm{g}$ of MTT (3- (4,5-dimethyltiazole-2-yl) salt2,5-diphenyltetrazolium bromide) (Sigma Aldrich, USA) diluted in $100 \mu / \mathrm{mL}$ phosphate buffer saline (PBS) and were incubated for $3 \mathrm{~h}$. One hundred microliter of stopper reagent (10\% SDS (Merck, Germay) in $0.1 \mathrm{~N} \mathrm{HCl}$ (Merck, Darmstadt, Germany) was added and the microplate was incubated overnight at room temperature and protected from light. The absorbance at $595 \mathrm{~nm}$ was measured by a microplate reader (Biorad, Japan). The assay was conducted in triplicate for each concentration. The $\mathrm{IC}_{50}$ of PGV-0 was obtained from previous report (Septisetyani, et al., 2008), while the $\mathrm{IC}_{50}$ of 5 -FU was also determined by MTT assay with a serial concentration of $100,200,300,500$, dan $1000 \mu \mathrm{M}$.

Percentage of cell viability was calculated to determine $\mathrm{IC}_{50}$ by a linear regression analysis (Doyle and Griffiths, 2000). For cytotoxic combination assay, combination index (CI) was calculated based on the combination index method (Reynolds and Maurer, 2005) as follow: $\mathrm{CI}=\left(\mathrm{D}_{\mathrm{PGV}-0} / \mathrm{Dx}_{\mathrm{PGV}-0}\right)+$ $\left(\mathrm{D}_{5-\mathrm{FU}} / \mathrm{Dx}_{5-\mathrm{FU}}\right)$, whereas $\mathrm{D}$ is the concentration of respective tested chemicals in combination assay and 
Dx is the calculated concentration of single test chemicals (obtained from the percent extrapolation of linear regression equation used to determine $\mathrm{IC}_{50}$ ) which caused the equal cell viability to the combination treatment (x). The value of CI is used to determine the potential effect given by the chemical combinations, whether synergistic (CI $<0.1$ very strong; 0.1-0.3 strong; 0.3-0.7 synergistic; 0.7-0.9 weak), additive (CI 0.9-1.1), or antagonistic (CI 1.11.45 weak; $1.45-3.3$ antagonistic; >3.3 strong).

\section{Cell cycle modulation}

A total of $1 \times 10^{6}$ cells/wells were distributed into a 6-well plate. After $48 \mathrm{~h}$ adaptation, the cells were treated with various concentrations of PGV-0, 5-FU, or combination of them and then were incubated for 12 or $24 \mathrm{~h}$. At the end of the incubation, floated and attached cells were collected, transferred into a microtube, and then centrifuged (2000 rpm, 3 minutes).After discarding the supernatant and washing in PBS, cell precipitates were washed with cold PBS and propidium iodide
(PI) reagent (5\% PI (Sigma Aldrich, USA)/7\% triton X-100 (Merck, Germany)/PBS) was added. The microtube was incubated in a $37^{\circ} \mathrm{C}$ water bath for 10 mniutes and protected from light. The cell suspension was homogenized again, transferred into flowcyto-tube, and directly analyzed by a flowcytometer (FASC Calibur, Beckton Dickinson). Quantification of the cells in different phases of cell cycle was analyzed by Cell Quest software.

\section{RESULTS}

\section{Cytotoxicity of 5-FU in WiDr cells}

5-FU showed cytotoxic effects on a dosedependent manner in WiDr cells (Fig. 1). The $\mathrm{IC}_{50}$ value of 5 -FU was $496 \mu \mathrm{M}$. Therefore, the cells showed lower sensitivity under 5-FU treatment compared to PGV-0 treatment with an $\mathrm{IC}_{50}$ of $45 \mu \mathrm{M}$ (Septisetyani, et al., 2008). These $\mathrm{IC}_{50}$ values were used to determine the concentration for cytotoxic combinaton assay as described in the Materials and Methods.

A

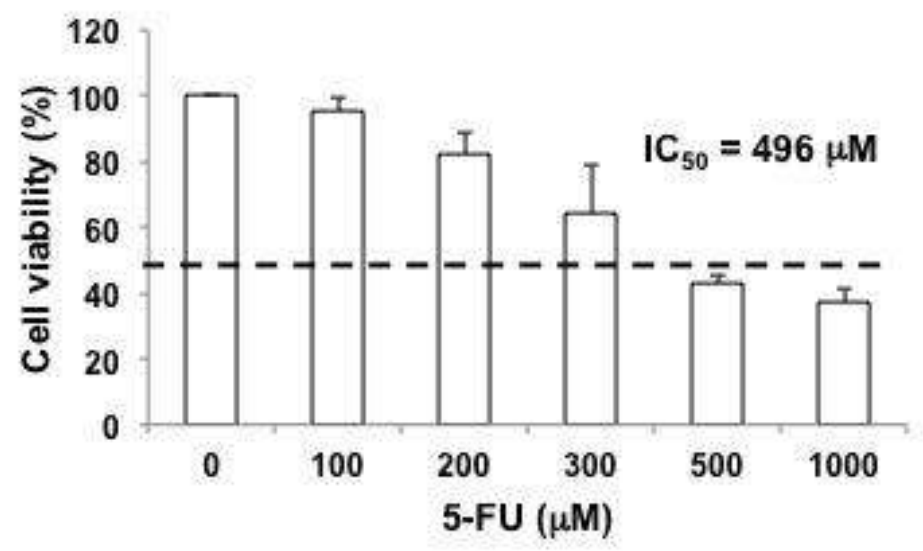

B

Control

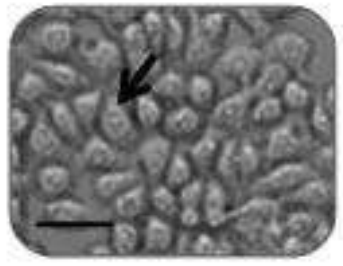

5-FU $(\mu \mathrm{M})$

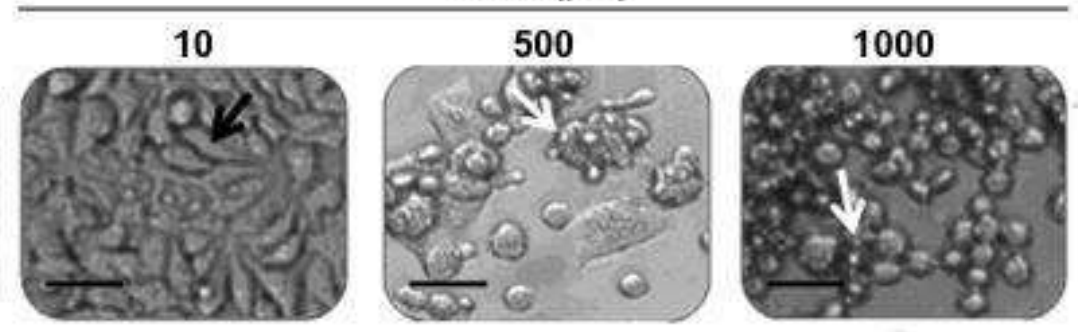

Figure I. Cytotoxicity of 5-fluorouracil in WiDr cells. Cells were treated with a serial concentration of 5-floroutacil (5FU) and incubated for $24 \mathrm{~h}$, and then were assayed by MTT assay. The histogram of 5-FU treatment demonstrated the phenomenon of dose-dependent cytotoxicity (A). Cell morphology underwent significant changes under 5-FU treatments compared to control (B). Black arrow indicated a live cell; white arrow indicated a cell undergoing a morphological change. The cell morphology was observed by an inverted microscope. Scale bars $=50 \mu \mathrm{m}$. 
PGV-0 synergistically increased cytotoxic potency of 5-FU in WiDr cells

Looking at the high cytotoxic potency of PGV-0, it is necessary to observe its potential as a combination agent for 5-FU in colon cancer. The result of cytotoxic combination assay of PGV-0 and 5-FU showed a strong additive effect at low concentration of PGV-0 $(6.25 \mu \mathrm{M})$ with CI value of 0.98 and 1.09 (Table 1). This value indicates that the combined cytotoxic effect is equal to the sum of each effect on a single treatment, whereas synergism shows that the combined cytotoxic effect is greater when compared to the sum of each effect on a single treatment. At higher concentrations there was no additive nor synergism effect because each compound has already exhibited strong cytotoxic effects. Histograms illustrated the cytotoxic combination assay of PGV-0 and 5-FU can be seen in Fig. 2A.

Table I. Combination index $(\mathrm{Cl})$ values of cytotoxic combination assay of Pentagamavunone-0 (PGV-0) and 5fluorouracil (5-FU) in WiDr cells

\begin{tabular}{|c|c|c|c|c|c|}
\hline \multirow{2}{*}{\multicolumn{2}{|c|}{$(\mu \mathrm{M})$}} & \multicolumn{4}{|c|}{ PGV-0 } \\
\hline & & 6.25 & 12.5 & 18.75 & 25 \\
\hline & 87.5 & 1.13 & 1.61 & 1.72 & 1.02 \\
\hline & 175 & $0.98^{*}$ & 1.58 & 1.54 & 1.14 \\
\hline ? & 262.5 & $1.09^{*}$ & 1.60 & 1.61 & 1.08 \\
\hline ก่ & 350 & 1.16 & 1.58 & 1.73 & 1.16 \\
\hline
\end{tabular}

*additive effect. $\mathrm{Cl}$ values were calculated by the combination index method (Reynolds and Maurer, 2005).
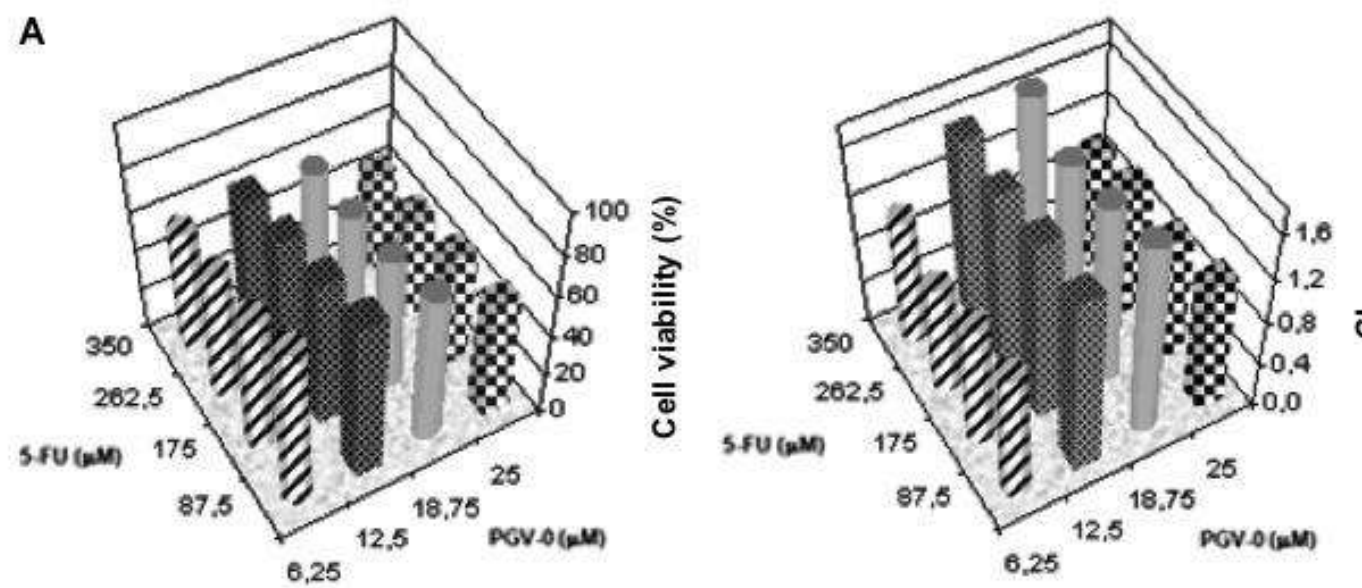

B
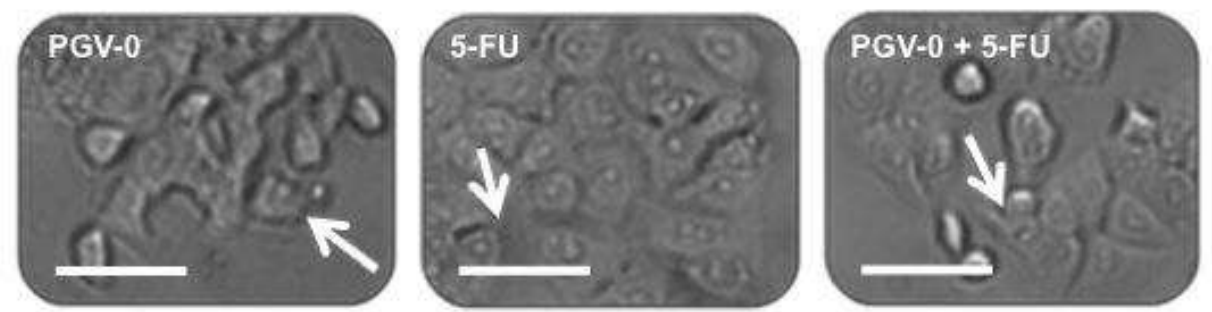

Figure 2. Pentagamavunone-0 at a low concentration reinforces cytotoxicity of 5-fluorouracil in WiDr cells. Cell viability under treatment of Pentagamavunone-0 (PGV-0) and 5-fluorouracil (5-FU) combination as described in the Materials and Methods was illustrated (A). Interpretation of additive effects were illustrated based on combination index $(\mathrm{Cl})$ values calculated in Table I (B). Strong additive effects were osberved at a low concentration of PGV-0. PGV-0 treatment at $6.25 \mu \mathrm{M}$ induces cell morphological changes (indicated by arrows), while $175 \mu \mathrm{M}$ of 5 -FU treatment caused changes in cell size. The combination treatment of PGV-0 and 5-FU at their respective concentartion showed morphological changes as well as cell size changes. The cell morphology was observed by an inverted microscope. Scale bars $=50 \mu \mathrm{m}$. 
Cell morphological observations showed that the 5-FU effect was equivalent to the effect of PGV0 . Treatment of low concentration of PGV-0 (6.25 $\left.\mu \mathrm{M}, 1 / 8 \quad \mathrm{IC}_{50}\right)$ showed membrane permeability changes so the boundaries between cells became unclear, while the 5 -FU treatment at $1 / 3$ of $\mathrm{IC}_{50}(175$ $\mu \mathrm{M})$ led to the sell size enlargement (Fig. 2B). Interestingly, under the combination treatment, boundaries between cells became unclear, cell size enlargements, and rounded cells were observed, indicating the ability of PGV-0 to increase 5-FU effectiveness in WiDr cells.

Cytotoxic effects can be caused by cell cycle arrest or induction of apoptosis. Mathematical calculations such as those done in the $\mathrm{CI}$ value calculation was used as a preliminary overview and as a base concentration to be used for further experiments. Hence, it is necessary to observe cell cycle modulation as a manifestation of physiological or morphological changes.

\section{PGV-0 single and in combination with 5-FU modulate WiDr cell cyle}

Cell cycle arrest is one of the main targets of cytotoxic agents. The analysis of cell cycle with flowcytometry showed slight inhibition in the G2/Mphase by $12 \mathrm{~h}$ incubation of PGV-0 at around $\mathrm{IC}_{50}$ $(50 \mu \mathrm{M})$ but did not induce apoptosis (Fig. 3 most upper panel). Nevertheless, after $24 \mathrm{~h}$ incubation cell numbers in the G2/M-phase decreased and 37.49\% cell accumulation occured in the subG1-phase, indicating an increase in apoptosis (Fig. 3 lower panel, Table 2). Inhibition of G2/M-phase resulted in the cell failure to undergo mitosis. Along with the time, the cell that failed to divide became a polyploid cell and eventually undergo apoptosis (Table 2).

Table 2. WiDr cell distribution of each phase of cell cycle after Pentagamavunone-0 (PGV-0), 5-fluorouracil (5FU), or their combination at various concentrations

\begin{tabular}{|c|c|c|c|c|c|c|c|}
\hline \multirow[t]{2}{*}{ Treatment } & \multirow{2}{*}{$\begin{array}{c}\text { Incubation } \\
\text { (h) }\end{array}$} & \multirow{2}{*}{$\begin{array}{c}\text { Concentration } \\
(\mu \mathrm{M})\end{array}$} & \multicolumn{5}{|c|}{$\%$} \\
\hline & & & SubG I & GI & $\mathbf{S}$ & G2/M & Polyploid \\
\hline Kontrol & 24 & - & 4.71 & 54.05 & 24.81 & 13,55 & 3.37 \\
\hline \multirow[t]{4}{*}{ PGV-0 } & 12 & 50 & 3.78 & 28.19 & 26.49 & $36.67 \mathrm{a}$ & 6.03 \\
\hline & 24 & 5 & 10.12 & 48.02 & 19.20 & 12.79 & 10.19 \\
\hline & & 25 & 8.46 & 33.46 & 24.18 & 13.66 & 20.76 \\
\hline & & 50 & $37.49 \mathrm{~b}$ & 18.42 & 20.92 & 17.45 & 6.07 \\
\hline \multirow[t]{3}{*}{ 5-FU } & 24 & 70 & 7.09 & 69.31 & 18.17 & 4.67 & 1.12 \\
\hline & & 175 & 3.02 & 65.01 & 11.12 & 7.27 & 13.89 \\
\hline & & 700 & 7.99 & 59.89 & 15.87 & 8.07 & 8.49 \\
\hline \multirow[t]{3}{*}{ PGV-0 + 5-FU } & 24 & $5-700$ & 8.86 & 57.90 & 16.65 & 8.05 & 8.88 \\
\hline & & $25-700$ & 9.78 & 39.76 & $34.20 c$ & 8.51 & 8.43 \\
\hline & & $6.25-175$ & 2.23 & 74.52 & 12.89 & 6.60 & 4.03 \\
\hline
\end{tabular}

${ }^{a} \mathrm{G} 2 / \mathrm{M}$-phase accumulation after $12 \mathrm{~h}$ treatment of PGV-0

${ }^{\mathrm{b}} \mathrm{SubG1}$-phaseaccumation, indicating apoptosis induction after $24 \mathrm{~h}$ treatment of PGV-0

${ }^{\mathrm{c}}$ Combination of PGV-0 and 5-FU resulted in S-phase arrest 


\section{Control}

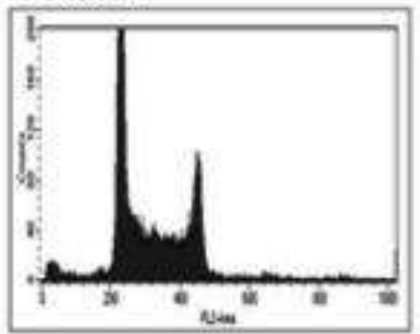

\section{Single treatment $(24 \mathrm{~h})$}
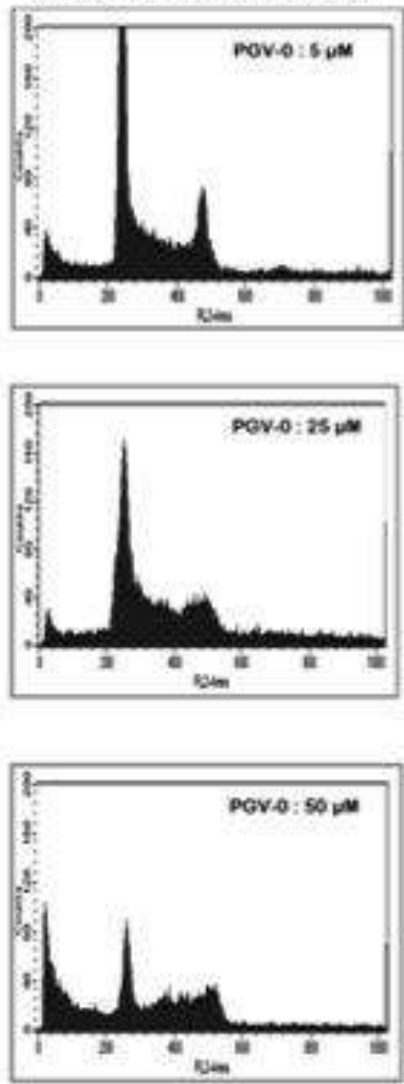

\section{Single treatment $(12 \mathrm{~h})$}

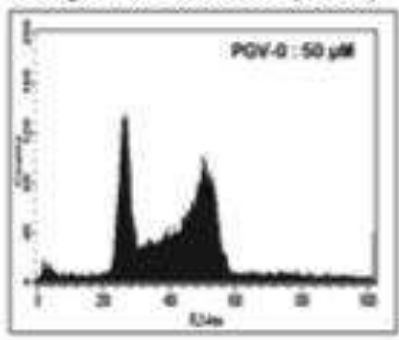

\section{Combination treatment $(24 \mathrm{~h})$}
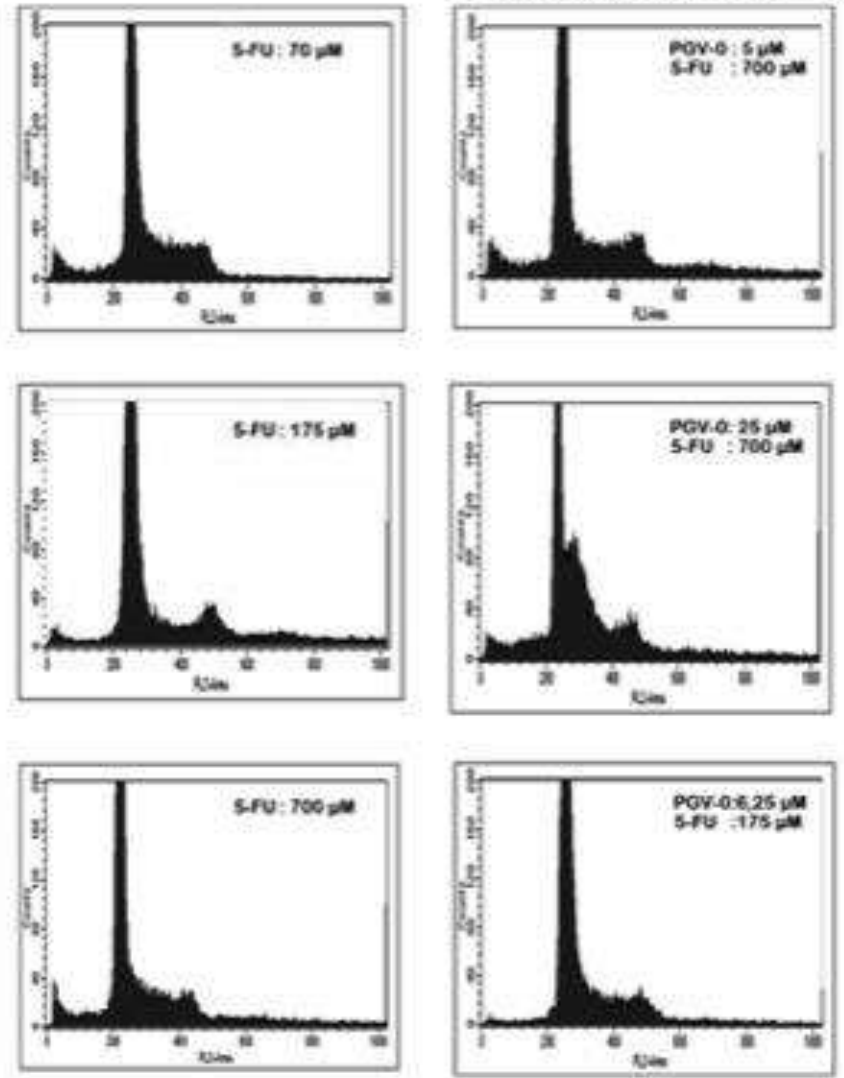

Figure 3. Analysis of WiDr cell cycle with flowcytometry after single treatment of Pentagamavunone-0 or in combination with 5-fluorouracil.Cells were treated with Pentagamavunone-0 (PGV-0), 5-fluorouracil (5-FU), or the combination of them at various concentrations. Cells were washed with cold PBS, centrifuged, PI reagents were added, and then read by FACS Caliburflowcytometry. The analysis was conducted with Cell Quest program. Treatment of PGV-0 for $12 \mathrm{~h}$ showed a slight inhibition in the G2/M-phase, whereas after $24 \mathrm{~h}$ incubation apoptosis increased. 5-FU indicates inhibition in the GI-phase. The combination of PGV-0 $(25 \mu \mathrm{M})$ and 5-FU $(700 \mu \mathrm{M})$ showed synergism in the S-phase inhibition. 
The inhibitory target of PGV-0 and 5-FU occured at different cell cycle phases as shown in Fig. 3. The G2/M-phase inhibition occured after PGV-0 treatment, whereas 5-FU, corresponding to its inhibition target on the activity of thymidilate synthase (TS) (Giovannetti, et al., 2007), inhibited the cell to enter the S-phase and increased cell accumulations in the G1-phase. The combination of PGV-0 and 5-FU at low concentrations producing a strong additive effect (CI 0.98) (Table 1) still showed the dominance of the 5-FU effect, which is the G1-phase inhibition (Fig. 3, Table 2), possibly because the PGV-0 effect on the cell cycle inhibition has not been occurred yet. Interestingly, increasing PGV-0 concentration (around a half of $\mathrm{IC}_{50}$ ) in combination with 5-FU shifted the cell cycle into the $\mathrm{S}$-phase inhibition. It is possible if the incubation is continued (i.e., for $48 \mathrm{~h}$ ) the triggering of apoptosis will be greater.

Overall, the observed effect of the cell cycle analysis was consistent with the results of the cytotoxic combination assay: the combination of PGV-0 and 5-FU for $24 \mathrm{~h}$ incubation did not show a synergistic in apoptosis induction. Synergism was demonstrated by the combination of PGV-0 and 5$\mathrm{FU}$ in the S-phase arrest. The combination of PGV-0 and 5-FU in various concentrations with longer incubation periods needs to be observed further to obtain optimal cell cycle inhibition resulting in increased effectiveness of 5 -FU in inducing cell apoptosis.

\section{DISCUSSION}

The main chemotherapeutic agent in colon cancer, 5-FU, showed a lower cytotoxic effect when compared to PGV-0. 5-FU, a pyrimidine analog, works selectively by inhibiting TS activity as the main mechanism of its cytotoxic effects (Shah and Schwartz, 2001). Although 5-FU may induce cellcycle inhibition and apoptosis via pathways dependent or independent of p53 activity, 5-FU shows a low cytotoxicity in colon cancer cells WiDr. The 5-FU chemoresistency in WiDr cells is probably due to mutations in the $\mathrm{p} 53$ tumor suppressor gene (Backus, et al., 2001) and the overexpression of TS (Sigmond, et al., 2003) and cyclooxygenase-2 (COX-2) (Palozza, et al., 2005). 5-FU cytotoxic activity was not much different when WiDr was transfected with a vector encoding normal p53 (Backus, et al., 2001). Therefore, increased sensitivity of WiDr cells, representing 5-FUresistant-colon cancer cells, is necessary to improve the effectiveness of 5-FU treatment.

PGV-0 is one of the potential curcumin analogs to be developed as a chemopreventive or cochemotherapy agent. PGV-0 and Pentagamavunone1 (PGV)1, another curcumin analogs, have higher cytotoxicity and induce apoptosis strongly than curcumin in WiDr cells (Septisetyani, et al., 2008). Both of curcumin analogs also induce a proapoptotic protein, Bax, and $\mathrm{COX}-2$ in WiDr cells (Septisetyani, et al., 2008). Thus, further investigation on the potency of PGV-0 and other curcumin analogs as co-chemotherapy agent for colon cancer is important.

Hermawan, et al. (2011) reported that PGV-0 and PGV-1 are a potent co-chemotherapy agents for breast cancer cells by increasing apoptotic induction of doxorubicin and modulating cell cycle in MCF-7 breast cancer cell line. More importantly, PGV-0 and PGV-1 synergisitically enhance sensitivity of MCF7-doxorubicin-resistant cells thorugh inhibition of HER2 and activation of NF- $\mathrm{kB}$ (Meiyanto, et al., 2014). Accordingly, curcumin analogs, including PGV-0, have a prospect to be developed as cochemotherapy agent for another type on cancer, including colon cancer.

In this present study, PGV-0 showed the additive potency as a combination agent for 5-FU in 5-FU-resistant-colon cancer cells by modulating cell cycle and therefore shifting the cell accumulation into the S-phase after $24 \mathrm{~h}$ treatment. It is possible if the incubation time is prolonged, the cells will die. Considering that low concentration of PGV-0 in WiDR was able to induce apoptosis strongly than 5$\mathrm{FU}$, it is likely that the dying cells are also go thorugh apoptosis. However, further investigated is needed to prove this hypothesis and also to reveal the molecular mechanisms behid those above findings.

Recent report by Meiyanto, et al. (2018) revealed that PGV-1 synergitically sensitizes WiDr cell to 5-FU by inhibiting NF-kB activation. Similar to PGV-0, PGV-1 also enhances S-phase arrest by 5 FU. Interestingly, after $48 \mathrm{~h}$ incubation, the combination treatment of PGV-1 and 5-FU significantly increases the cell accumulation is the Sphase and subG1-phase. In fact, PGV-1 and 5-FU 
combination suppresses level of cyclin D1, a cell cycle regulator. Furthermore, PGV-1 inhibits NF-kB activation in a luciferase reporter assay and decreases COX-2 expression, both at mRNA and protein level. Taken together those findings of PGV1 in WiDr cells, with further examinations it is possible that PGV-0 also will perform similar mechanisms.

\section{CONCLUSION}

Analog curcumin PGV-0 has the potential to be developed as a chemopreventive agent or cochemotherapy in colon cancer therapy.

\section{ACKNOWLEDGEMENT}

The authors are grateful to CRC Faculty of Pharmacy UGM for providing PGV-0.

\section{REFERENCES}

Aggarwal, B.B., Kumar, A., Aggarwal, M.S. and Shishodia, S., 2005, Curcumin Derived from Turmeric (Curcuma longa): A Spicefor All Seasons, In: Ravindran, P.N., Babu, K.N. and Sivaraman, K., editors., 2005, Turmeric the genus Curcuma, Boca Raton: CRC Press. PP. 349-387.

Arkenau, H.T., Rettig, K. and Porschen, R., 2005, Adjuvant Chemotherapy in Curative Resected Colon Carcinoma: 5fluorouraci//leucovorin versus High-dose 5fluorouracil 24-h Infusion, Int. J. Colorectal Dis., 20(3), 258-26I.

Backus, H.H.J., Pinedo, H.M., Wouters, D., Kuiper, C.M., Jansen, G. and van Groeningen, C.J., 200I, Differences in the Induction of DNA Damage, Cell Cycle Arrest, and Cell Death by 5-dluorouracil and Antifolates, Oncol. Res., I 2(5), 23|-239.

Da'i, M., Margono, S.A., Meiyanto, E. and Jenie, U.A., 2007, Geometric Isomers and Cytotoxic Effect on T47D Cells of Curcumin Analogues PGV-0 and PGV-I, Indones. J. Pharm., I8(I), 40-47.

Da'i, M., 2003, Antiproliferative Effects of Pentagamavunon-0 on Raji, HeLa, and Myeloma
Cells, Thesis, Universitas Gadjah Mada, Yogyakarta.

De Angelis, P.M., Svendsrud, D.H., Kravik, K.L. and Stokke, T., 2006, Cellular Response to 5 fluorouracil (5-FU) in 5-FU-resistant Colon Cancer Cell Lines During Treatment and Recovery, Mol. Cancer, 5(20), I-25.

Doyle, A. and Griffiths, J.B., 2000, Cell and Tissue Culture for Medical Research, New York: John Willey and Sons.

Giovannetti, E., Backus, H.H.J., Wouters, D., Ferreira, C.G., van Houten, V.M.M., Brakenhoff, R.H., et al., 2007, Changes in The Status of p53 Affect Drug Sensitivity to Thymidylate Synthase (TS) Inhibitors by Altering TS levels, Br. J. Can., 96(5), 769-775.

Hermawan, A., Fitriasari, A., Junedi, S., Ikawati, M., Haryanti, S., Widaryanti, B., et al., 20I I, PGV. 0 and PGV-I Increased Apoptosis Induction of Doxorubicin on MCF-7 Breast Cancer Cells, Pharmacon, I 2(2), 55-59.

Jemal, A., Siegel, R., Ward, E., Murray, T., Xu, J., Smigal, C., et al., 2006, Cancer Statistics 2006, Cancer J. Clin., 56(2), I06-I30.

Meiyanto, E., Margono, S.A. and Da'i, M., 2003, Antiproliferative Effect of PGV-O (A Curcumin Analogue) Against HeLa Cells, Gama Sains, 5(3), 200-206.

Meiyanto, E., Agustina, D., Margono, S.A. and Da'i, M., 2006, PGV-0 Induces Apoptosis on T47D Breast Cancer Cell Line Through Caspace-3 Activation, Yarsi Medical J., I 5(2), 75-79.

Meiyanto, E., Putri, D.D.P.P., Susidarti, R.A., Murwanti, R., Sardjiman, Fitriasari, A., et al., 2014, Curcumin and Its Analogues (PGV-0 and PGV-I) Enhance Sensitivity of Resistant MCF-7 Cells to Doxorubicin Through Inhibition of HER2 and NF-KB Activation, Asian Pac. J. Cancer Prev., I 5(I), I79-I84.

Meiyanto, E., Septisetyani, E.P., Larasatim Y.A. and Kawaichi, M., 2018, Curcumin Analog Pentagamavunone-I (PGV-I) Sensitizes WiDr Cells to 5-fluorouracil Through Inhibition of NF-kB Activation, Asian Pac. J. Cancer Prev., I9(I), 49-56.

Mosmann, T., 1983, Rapid Colorimetric Assay for Cellular Growth and Survival: Application to Proliferation and Cytotoxicity Assays, J. Immunol. Methods, 65(I-2), 55-63. 
National Molecule Team, 200la, Research Report: Acute Toxicity, Teratogenicity, and Ulcerogenicity of PGV-O, PGV-I, and HGV-I in Rats dan Rabbits, Yogyakarta: Universitas Gadjah Mada.

National Molecule Team, 200 Ib, Research Report: Subhronic Toxicity Assay of PGV-O, PGV-I, and HGV-I in Rats dan Rabbits, Yogyakarta: Universitas Gadjah Mada.

Nurulita, N.A. and Meiyanto, E., 2006, The Anticancer Effects of Pentagamavunon-0 (PGV-0) to T47D Cell Line Induces by 17-bestradiol Thorugh Apoptosis Induction and Angiogenesis Suppression Mechanisms, Sains Kesehatan, 19(I), 109-117.

Palozza, P., Serini, S., Maggiano, N., Giuseppe, T., Navarra, P., Ranelletti, F.O., et al., 2005, $\beta$ carotene Downregulates the Steady-state and Heregulin- $\alpha$-induced COX-2 Pathways in Colon Cancer Cells, J. Nutr., I35(I), 129136.

Reksohadiprodjo, M.S., Timmerman, H., Sardjiman, Margono, S.A., Martono, S., Hakim, L.R., et al., 2004, Derivatives of Benzylidenecyclohexanone, Benzylidenecyclopentanone, and Benzylidene Acetone, and Therapeutic Uses Thereof, USA: United States Patent.

Reynolds, C.P. and Maurer, B.J., 2005, Evaluating Response to Antineoplastic Drug
Combinations in Tissue Culture Models, Methods Mol. Medicine., I I 0, I73-I83.

Septisetyani, E.P., Ikawati, M., Widaryanti, B. and Meiyanto, E., 2008, Apoptosis Mediated Cytotoxicity of Curcumin Analogues PGV-O and PGV-I in WiDr Cell Line, Proceeding, Yogyakarta: Molecular Targeted Therapy Symposium, ISBN: 978-979-95I07-6-I, PP. 48-56.

Shah, M.A. and Schwartz, G.K., 200I, Cell Cyclemediated Drug Resistance: An Emerging Concept in Cancer Therapy, Clin. Can. Res., 7(8), 2|68-2|8|.

Sharma R.A., Euden S.A., Platton S.L., Cooke D.N., Shafayat A. and Hewitt H.R., 2004, Phase I Clinical Trial of Oral Curcumin: Biomarkers of Systemic Activity and Compliance, Clin. Can. Res., 10(20), 6847-6854.

Sigmond J., Backus H.H., Wouters D., Temmink O.H., Jansen, G. and Peters, G.J., 2003, Induction of Resistance to the Multi Targeted Antifolate Pemetrexed (ALIMTA) in WiDr Human Colon Cancer Cells is Associated with Thymidylate Synthase Overexpression, Biochem. Pharmacol., 66(3), 431-438.

Suwaldi and Oetari., 2004, Research Report: An Attempt to Increase PGV-O Absorption in vitro by An Inverted Intestine Method, Yogyakarta: Universitas Gadjah Mada. 